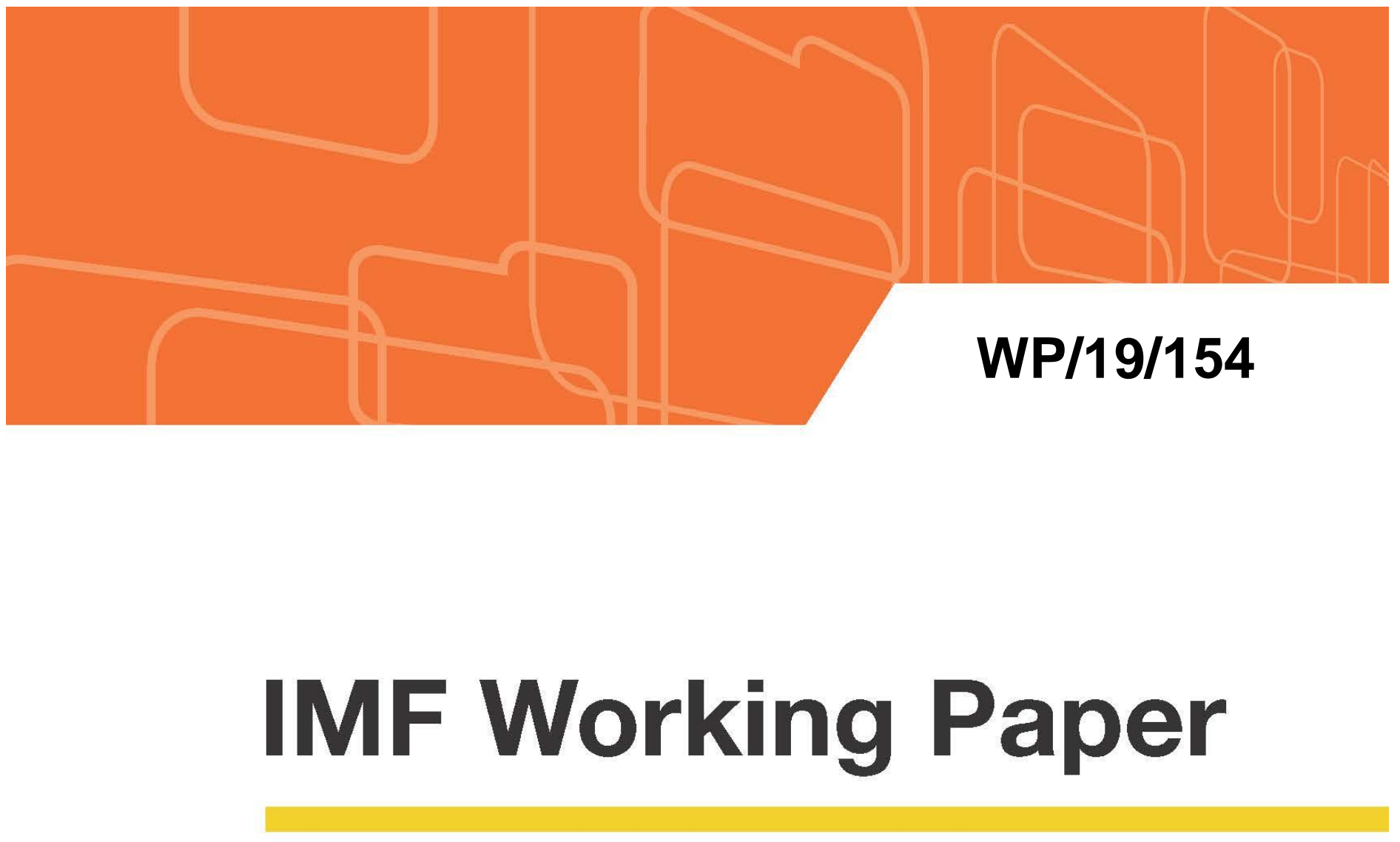

\title{
New Insights into ECCU's Tourism Sector Competitiveness
}

by Manuk Ghazanchyan, Li Zhao, Steve Brito and Vivian Parlak

IMF Working Papers describe research in progress by the author(s) and are published to elicit comments and to encourage debate. The views expressed in IMF Working Papers are those of the author(s) and do not necessarily represent the views of the IMF, its Executive Board, or IMF management.

$$
\text { I N T E R N A T I O N A L M O N E T A R Y }
$$




\title{
IMF Working Paper
}

Western Hemisphere Department

\section{New Insights into ECCU's Tourism Sector Competitiveness \\ Prepared by Manuk Ghazanchyan, Li Zhao, Steve Brito and Vivian Parlak}

Authorized for distribution by Ding Ding

July 2019

\section{IMF Working Papers describe research in progress by the author(s) and are published to} elicit comments and to encourage debate. The views expressed in IMF Working Papers are those of the author(s) and do not necessarily represent the views of the IMF, its Executive Board, or IMF management.

\begin{abstract}
Tourism has become the main driver of economic growth and employment and the most important source of income in the ECCU. Preserving and, possibly, enhancing the competitiveness of the tourism product is key for these countries. Unfortunately, the evidence shows that tourism arrivals to the ECCU have been declining slightly while global demand for tourism is on the rise. The objective of this paper is to study the structural determinants of competitiveness for the ECCU, defined as the relative cost advantage over other touristic regions (Di Bella, Lewis, and Martin 2007). Using a gravity model, we show that proximity to North American and European markets is indeed an important competitive advantage for the ECCU. However, despite this advantage, and, in some cases, specialization in high-end tourism, regression analysis shows that arrivals to the ECCU are sensitive to relative prices. Our simulations show that mitigating supply-side constraints would improve the ECCU's competitiveness and allow the region to regain global market shares.
\end{abstract}

JEL Classification Numbers: Z30, Z31, Z32, Z38, D42.

Keywords: price elasticity, income elasticity, Eastern Caribbean Currency Union (ECCU), gravity model, tourism arrivals and expenditure, tourism infrastructure, doing business, governance indicators.

Author's E-Mail Address: mghazanchyan@imf.org; lzhao@imf.org; sbrito@imf.org; vparlak@imf.org; 


\section{CONTEnTS}

ABSTRACT_________________________________________ 2

I. INTRODUCTION__________________________________ 4

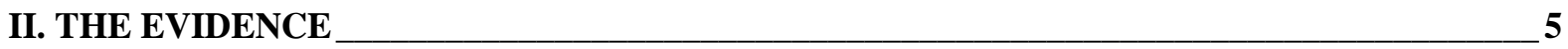

III. STYLIZED FACTS ON REGIONAL SUPPLY FACTORS __ 7

IV. PROXIMITY IS A KEY COMPETITIVE ADVANTAGE ___ 8

V. MODEL ON DETERMINANTS OF TOURISM ARRIVALS AND EXPENDITURES ___ 10

VI. REMOVING SUPPLY-SIDE CONSTRAINTS COULD BOOST COMPETITIVENESS AND

THE ECCU'S MARKET SHARE______ 11

VII. POLICY CONCLUSIONS _________________________ 14

We are very grateful to Leo Bonato, Nicole Laframboise, Johanna Schauer, Gonzalo Salinas, Takuji Komatsuzaki, Sonia Muñoz, Kotaro Ishi, Wayne Mitchell, Haobin Wang, Ding Ding, Mauricio Vargas, Bogdan Lissovolik, Paul Cashin, Carolina Castellanos, and all participants to seminars at the IMF and the ECCB for their helpful comments. We are also thankful to Luca Ricci and Ecuador team for generously sharing the market share model. Samira Kalla provided outstanding research assistance and Malika El Kawkabi and Sheng Tibung excellent administrative assistance. 


\section{INTRODUCTION}

Tourism has become the main driver of economic growth and employment in the ECCU ${ }^{1}$. The development of tourism shifted production and employment from traditional agriculture to the services sector with significant productivity gains and broader economic benefits. Preserving the competitiveness of tourism is therefore key for the region. Several studies have looked at the drivers of tourism in the Caribbean and the ECCU (for example, Archibald and others, 2008; Bineswaree, 2011; and Laframboise and others, 2014). Tashu (2013) looks at how the ECCU is positioned in the global tourism market and what factors drive its competitiveness. The aim

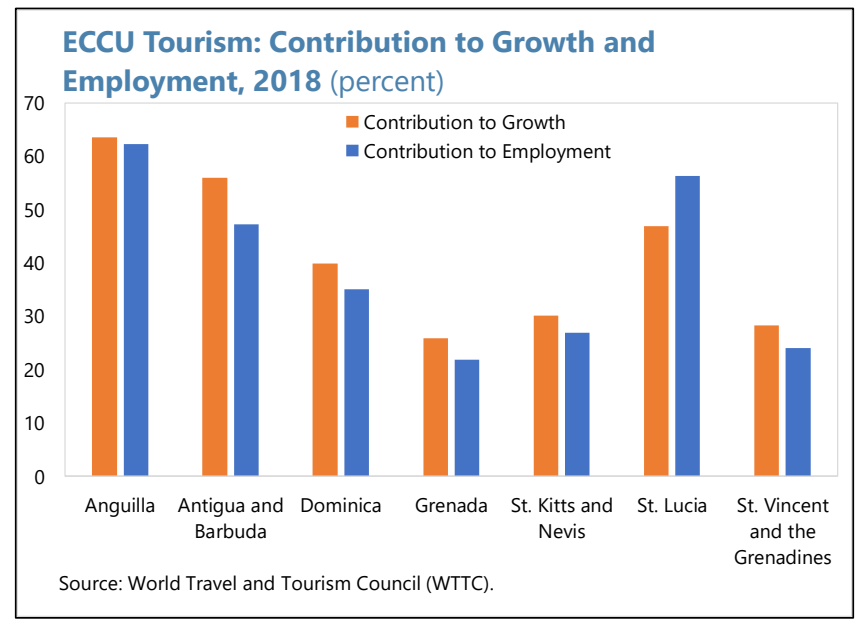
of this paper is to provide a fresh view on this issue, building on the existing literature.

The paper focuses on structural issues. ECCU members have their own currency, the Eastern Caribbean dollar, pegged to the U.S. dollar and supported by a quasi-currency board arrangement. This implies that ECCU members must rely on internal devaluation to adjust to relative price shocks and maintain competitiveness. Hence, this study does not focus on the ECCU exchange rate arrangement, which has served the region well, bringing low inflation and arguably better fiscal outcomes (see Imam 2010, Acevedo and Walker, 2013). ${ }^{2}$ Rather, the paper looks at how competitiveness can be improved by reducing supply side bottlenecks.

There is large scope to make the tourism product more affordable. Being close to the U.S. and European markets is a big competitive advantage for the ECCU as a tourism destination. However, our study shows that price is an important determinant of tourism arrivals in the ECCU and prices are high in the region ${ }^{3}$. Reducing them would imply attracting more tourists to medium-end destinations, where price elasticity is higher, substantially increasing the ECCU market share. Structural reforms that reduce the costs of doing business - including electricity and transportation costs and import tariffs — can

\footnotetext{
${ }^{1}$ ECCU members comprise Antigua and Barbuda, Dominica, Grenada, St. Kitts and Nevis, St. Lucia, St. Vincent and the Grenadines (all independent states) and Anguilla and Montserrat (UK overseas territories).

${ }^{2}$ For more on exchange rate competitiveness, please see Emilio, Sun, and Cashin (2010).

${ }^{3}$ In the econometric work that follows, prices are proxied by the REER. Owing to the short span of the data for the week at the beach index available only from 2014, it was not used in the regressions but rather in our discussions of prices and the cost structure in the region.
} 
indeed allow price reductions in medium-end destinations while increasing profitability and/or improving product quality in high-end destinations (Laframboise and others, 2014). ${ }^{4}$

The paper is organized as follows. Section II provides the motivation of the study, reviewing the evidence of persistently large current account deficits, a declining share of global tourism, and the ECCU's high prices compared with other tourism destinations. Section III provides background on key factors affecting tourist arrivals such as natural disasters and hotel and airline capacities. Section IV applies the gravity model to show the key role proximity plays for the ECCU's tourism inflows. Section V formally studies the determinants of tourism inflows to the ECCU. Section VI assesses the potential impact of structural reforms and Section VII concludes.

\section{THE EVIDENCE}

\section{Declining relative per capita incomes, rising current account deficits, and increasing external indebtedness have characterized the ECCU in the last twenty years. After a period of rapid catching up that ended in the 1990s, per capita output growth in the ECCU has lagged that of other emerging and developing economies and of the broader Caribbean while external current account deficits have risen. While a large portion of the deficits are financed by FDIs, the region has accumulated

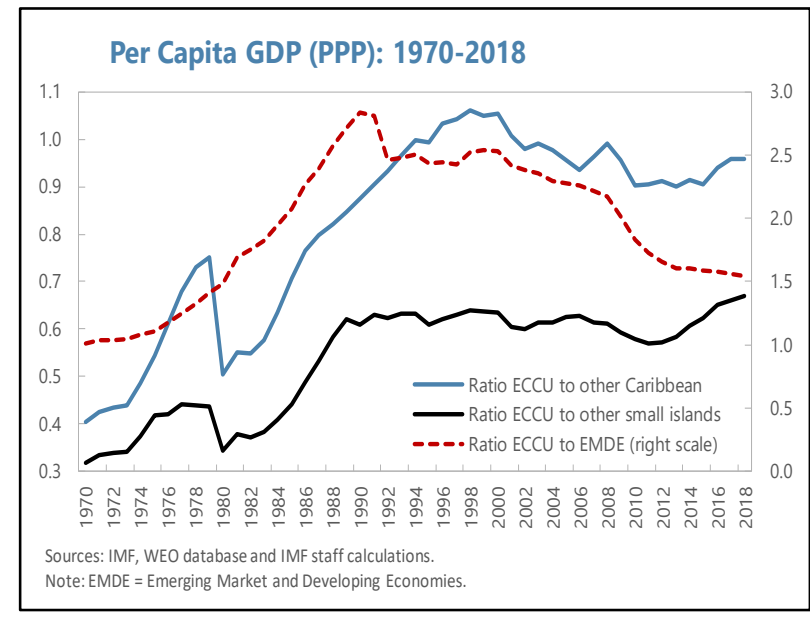 sizable external liabilities. External imbalances and high structural unemployment likely reflect a weak external position, and low competitiveness.}

\footnotetext{
${ }^{4}$ As part of its 2017-21 strategic plan, the ECCB has committed to support member countries to achieve a top-50 ranking on the World Bank's Doing Business Index in the next three years. This will include policy advice and quarterly consultations to reform processes and support specific initiatives, including the modernization of the legal framework and the establishment of a modern land registry.
} 

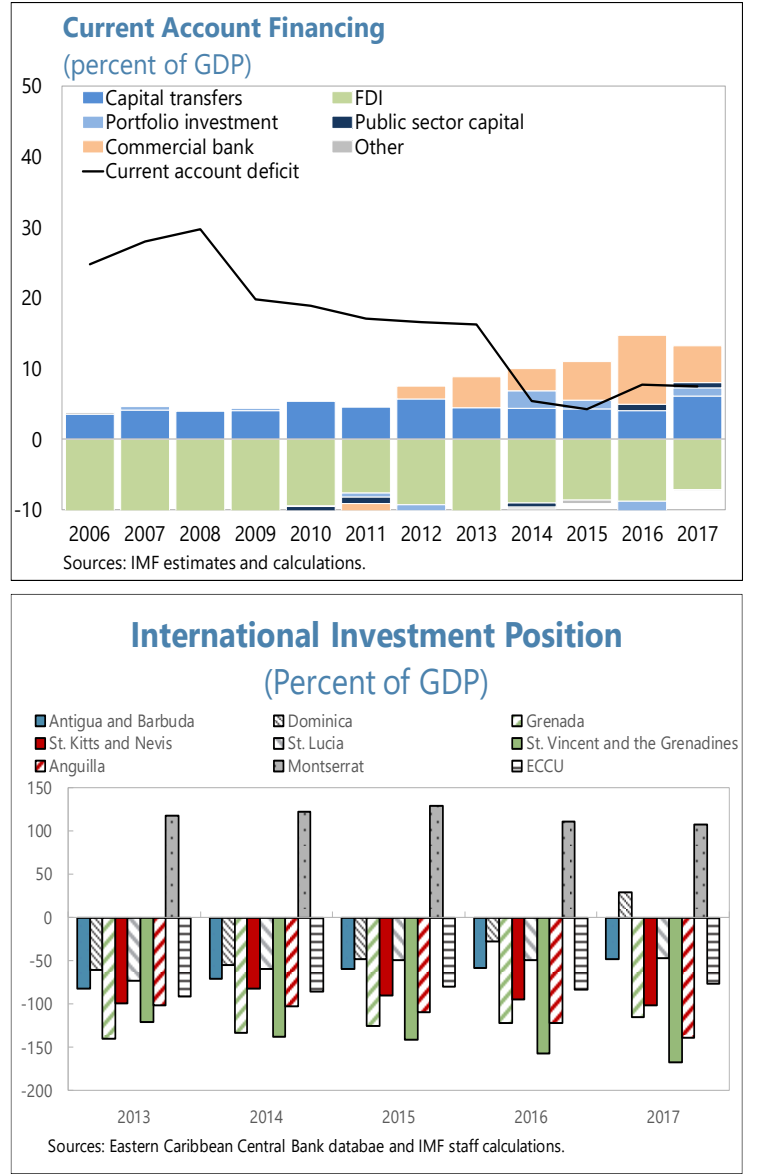

ECCU: Current Account Balance (In percent of GDP)

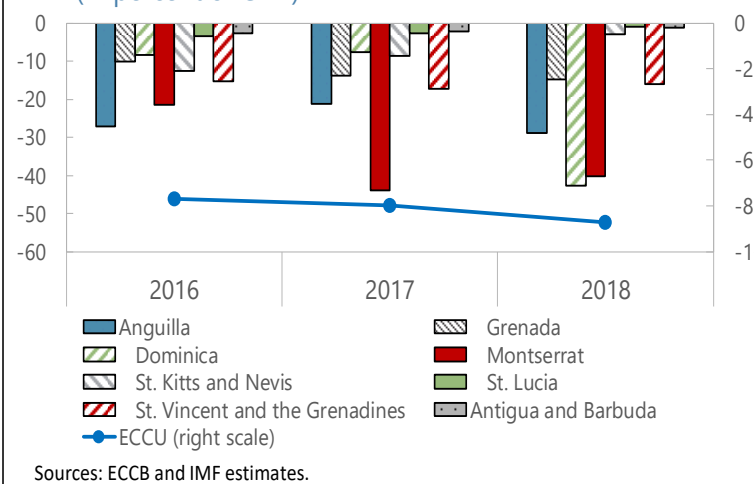

Sources: ECCB and IMF estimates.

Unemployment Rate (Percent)

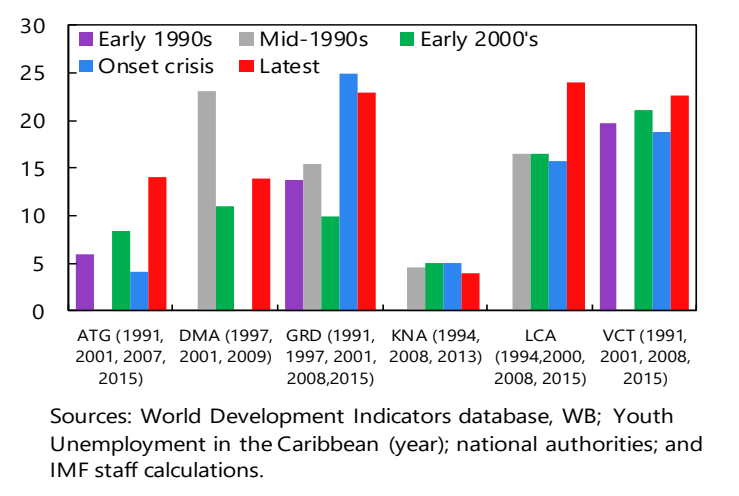

The ECCU's share of global tourism market has declined. Largely dependent on the North American and UK markets, tourism has become a key component of ECCU exports. Global tourism has expanded significantly in the last few years, with new origin countries like China entering the market. Tourism arrivals to the ECCU, however, have not increased as in other tourist destinations, especially in Africa, Asia, and the Americas. A similar trend can be observed in the broader Caribbean.

Tourist Arrivals to ECCU by Source Markets to Week at the Beach Index Country Groups, 2012

(In percent)

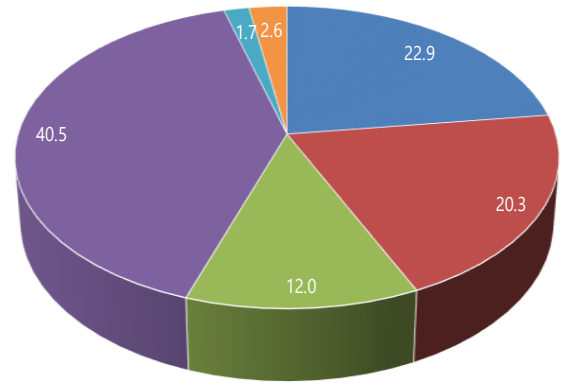

Source: UNWTO.
Tourist Arrivals to ECCU by Source Markets to Week at the Beach Index Country Groups, 2017

(In percent)

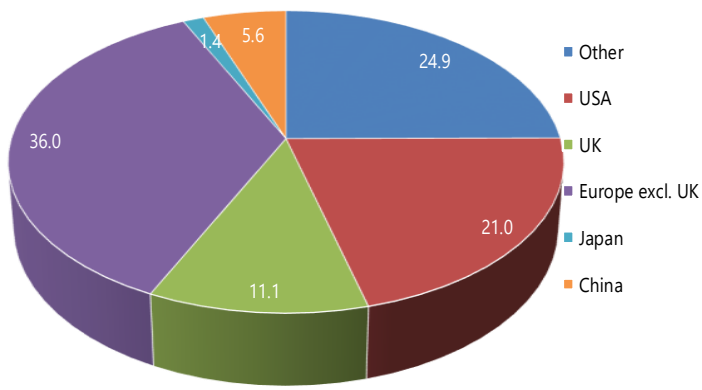

Source: UNWTO 
The loss of market share is explained mostly by the decline in traditional source markets, U.S, UK, and Canada, where demand for tourism services has continued to increase, with only a short pause during the Global Financial Crisis (GFC). Tourism arrivals to the ECCU have also declined as a share of total Caribbean tourism inflows. With the ECCU accounting for 10 percent of Caribbean GDP, ECCU members attract only about 5 percent of total Caribbean tourism stay-over arrivals.
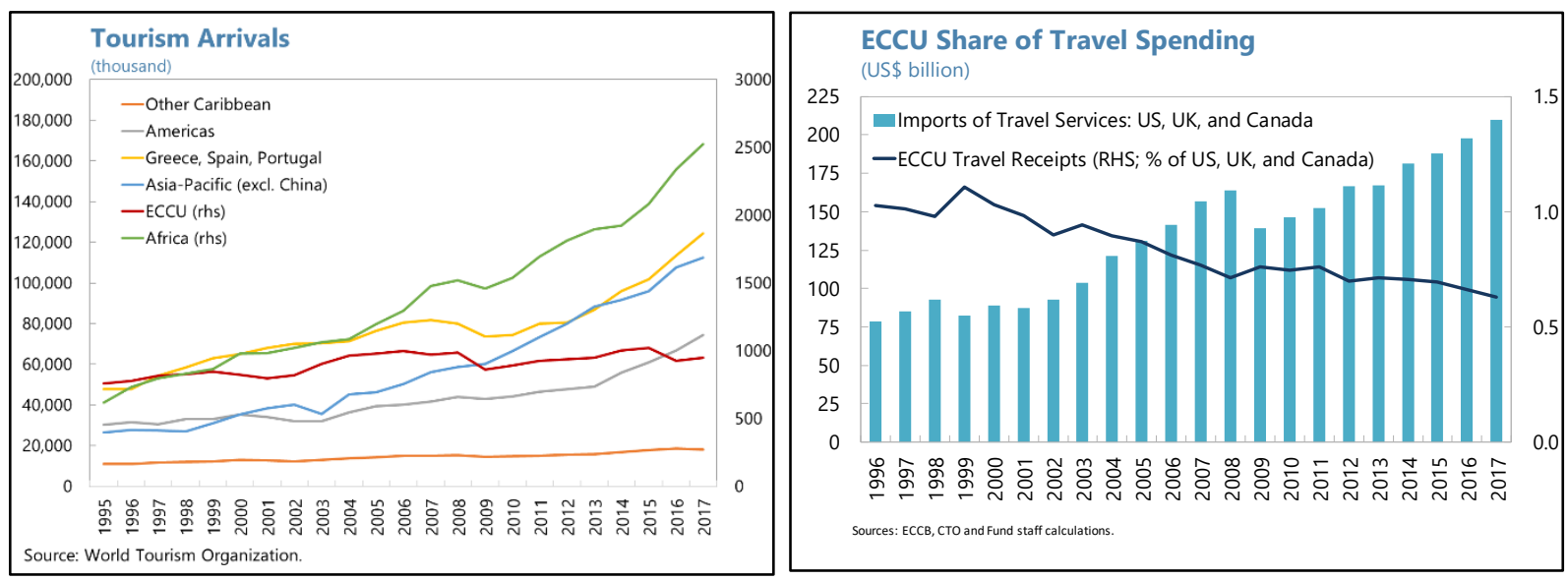

\section{STYlized Facts ON Regional SuPPly}

\section{The ECCU tourism product is amongst} the most expensive in the world, as shown by the Week-at-the-Beach index (IMF, 2018). Both ECCU members and the broader Caribbean are amongst the most expensive tourism destinations in the world. This may partly reflect the relatively large presence of high-end destinations in the ECCU. ${ }^{5}$

The region is vulnerable to hurricanes, storms, and floods, which affect arrivals. As an example, out of 511 catastrophes that happened in small states since 1950, 324 (more than 60 percent) occurred in the Caribbean. The impact of a hurricane on tourism for individual countries can be quite diverse. Romeu (2008) finds that tourism improves in some countries in the year following hurricanes relative to their neighbors spared by the disaster. We find that for the ECCU natural disasters do matter as there is a direct correlation between them and tourist arrivals, and the recovery can take
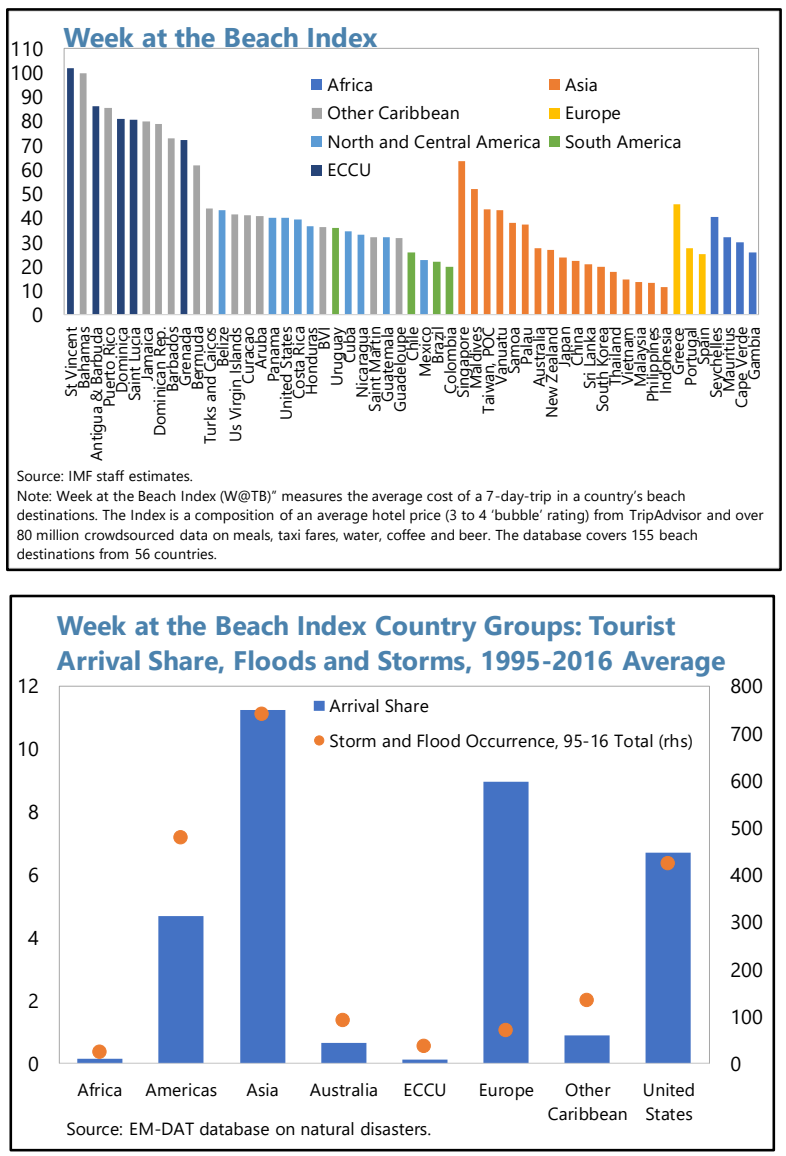

${ }^{5}$ Although all ECCU islands offer exclusive resorts, only Anguilla and St. Kitts and Nevis specialize in highend tourism (Lafambroise and others, 2014). 
longer than a year, as the experience with Hurricanes Irma and Maria in Dominica and Anguilla has shown (see also Acevedo, 2014 and Evridiki, 2008).

Airlift options for the ECCU have improved. The number of airlines serving all ECCU countries has increased in the last few years, so has the number of flights from the U.S., with some interruptions related to weather events, for example for St. Vincent and the Grenadines in 2016.

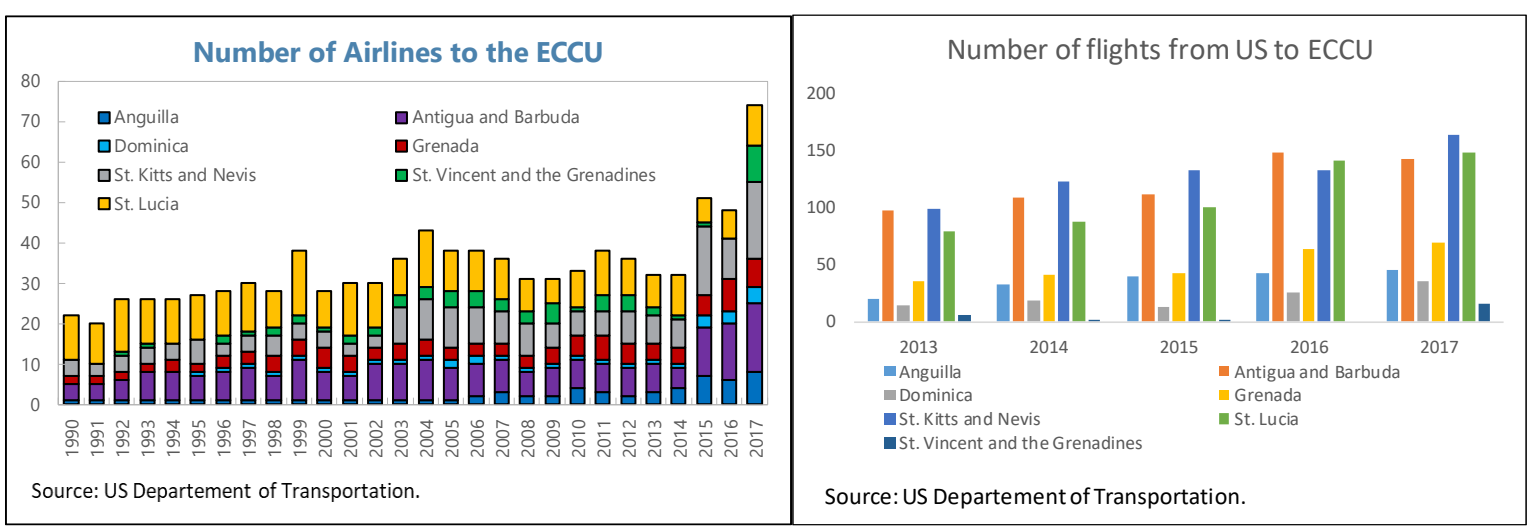

Hotel capacity in the ECCU is only 5 percent of the whole Caribbean, broadly equal to the tourism share of ECCU in the region. Hotel and airlift capacities are highest in St. Lucia and Antigua and Barbuda, the two top ECCU destinations. In the last five years, however, hotel capacity has declined in these two islands and in St. Vincent and the Grenadines owing to the closure of some hotels in the aftermath of the GFC. While in Grenada, in 2014, the significant increase in tourist arrivals was primarily accommodated by an increase in stayovers at large hotels. This is consistent with the opening of the large Sandals resort, which expanded capacity in the hotel sector by 225 rooms, increasing total capacity of the hotel segment by 12 percent.
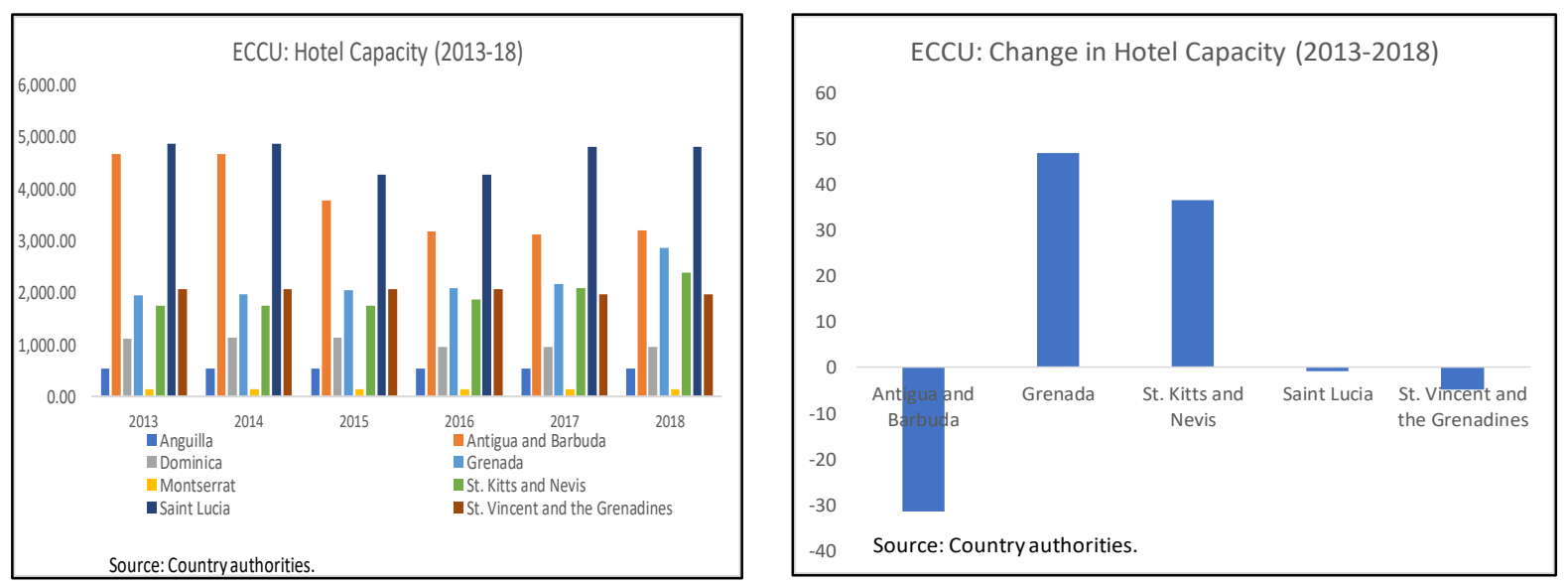

\section{Proximity is a Key Competitive Advantage}

To show the significance of proximity for the ECCU tourism market, we estimated a gravity model using countries and regions included in the Week-at-the-Beach index as comparators for the period of 1977-2017 (Table 1in the Appendix). The bilateral tourism data mainly come from the World Tourism Organization (WTO) database for non-ECCU 
countries and from the Caribbean Tourism Organization (CTO) for ECCU members. The data on distance and cultural and historical links between countries are from CEPII's GeoDist database. The natural disasters data are taken from Acevedo (2017) and the crime data from Laframboise and others (2014). The sample includes 55 tourist destinations and includes 19 Caribbean countries, and 31 advanced economies as source countries.

The estimated gravity model is as follows:

$$
\operatorname{LnTA}_{\mathrm{ijt}}=\alpha 0+\alpha 1 I_{i t}+\alpha 2 I_{j t}+\beta 1 \mathrm{Dist}_{i j}+\delta X_{i j}+\not{\gamma} \mathrm{Z}_{i}+\mathrm{e}_{\mathrm{ijt}}
$$

where the $\log$ of bilateral tourist arrivals to ECCU destination $i$ from advanced economy $j$ is a function of destination-year $\left(I_{i t}\right)$ and source-year $\left(I_{j t}\right)$ indicators that capture non-systemic tourism determinants of destination and source countries, (e.g., GDP), bilateral distance between the destination and source country population weighted distance, a vector $X_{i j}$ that includes other determinants of tourism flows such as whether countries share a common language or a colonial history, number of hotel rooms, number of airlines or air flights, number of hurricanes and storms and the crime rate, weighted average of US, Canada and UK incomes per Laframboise and others (2014), and the real effective exchange rate (REER).

\section{The gravity model shows that distance could be a major competitive advantage} for the ECCU. The estimated coefficients have the expected sign and the results are consistent with previous analysis (Acevedo and others, 2017). The coefficients for income and cultural and historical ties are positive and statistically significant. So is the capacity coefficient (hotel rooms).

Distance has the expected negative sign and is strongly significant, that is, after controlling for all other determinants,

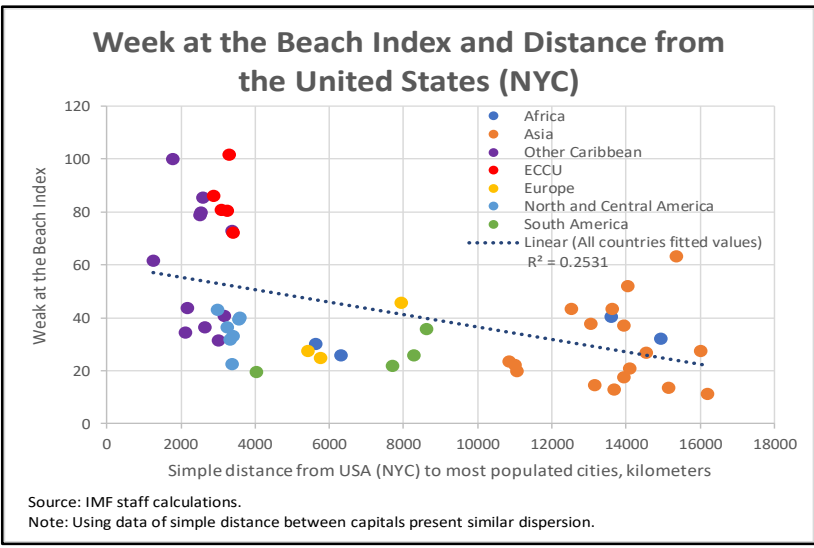
proximity to large traditional markets like the US and Europe gives the region a competitive edge. This finding is also consistent with Laframboise, (2014).
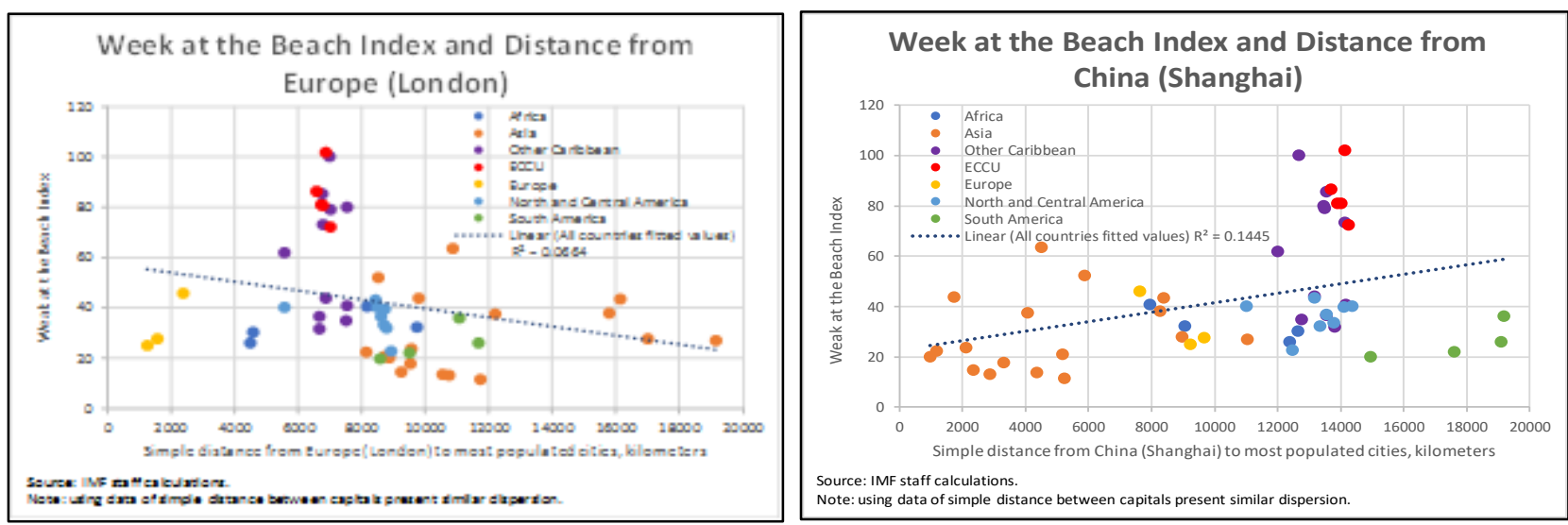
The impact of relative prices seems to be muted. The coefficient is negative as expected but is not statistically significant. The low impact of prices could be explained largely by the model specification itself and the larger sample used. ${ }^{6}$ Indeed, even within the broader Caribbean, prices vary substantially, with the ECCU being among the most expensive and other countries (including Aruba, Bermuda, British Virgin Islands, Cuba, Guadeloupe, Turks and Caicos) providing a much cheaper product.

\section{Model ON DETERMINANTS OF TOURISM ARRIVALS AND EXPENDITURES}

Following Laframboise and others (2014), we estimate dynamic panel regressions for ECCU members on an extending sample including 2017. The basic model is as follows: ${ }^{7}$

$$
\Delta \ln \left(\mathrm{Y}_{c t}\right)=\beta_{1} \Delta \ln (\mathrm{P}) c t+\beta_{2} U E_{c t}+\beta_{3} I_{c t}+\Delta \mathrm{X}_{c j}+\Delta \mathrm{e}_{c t}
$$

where $\Delta$ is the first-differenced operator, e.g., $\Delta \mathrm{Y}_{\boldsymbol{c} t}=\mathrm{Y} \boldsymbol{c t}-\mathrm{Y} \boldsymbol{c t}-\mathbf{1}$ and with year $\mathrm{t}=2000$, $2001 \ldots 2017$ and country $\mathrm{c}=1,2 \ldots 7$.

$\mathrm{Y}_{c t}$ is the number of tourism arrivals or expenditure in country $\mathrm{c}$ and year $\mathrm{t}$;

$\mathrm{P}_{c t}$ is the tourism-weighted real exchange rate of country $\mathrm{c}$ in year $\mathrm{t}$, with weight being the tourist arrival shares from US, UK, and Canada in 2010;

$\mathrm{UE}_{c t}$ is the tourism-weighted source country unemployment rate of country $\mathrm{c}$ in year $\mathrm{t}$;

Ict is the weighted average of US, Canada and UK income levels. Alternative specification included only US income level;

$\mathrm{X}_{c j}$ is a vector of time-varying explanatory variables ((i) supply factors: number of airlines reaching destinations or, alternatively, air flights and number of hotel rooms; (ii) other factors: homicide rate in destination countries, dummies for natural disasters and the September 11, 2001 terrorist attacks);

$\Delta \mathbf{e}_{\mathrm{ct}}$ is an error term.

Prices, income in source markets, natural disasters and flights are the key determinants of tourism arrivals to the ECCU. In table 2 in the Appendix, we show that: (i) ECCU

\footnotetext{
${ }^{6}$ Price elasticity is found to be statistically insignificant in a sub-sample of high-end destinations (Laframboise and others, 2014). The authors used the two criteria (i) the number of 4- and 5-star hotels as a share of total and (ii) GDP per capita above $\$ 15,000$ and found the following countries to be high end destinations: Anguilla, The Bahamas, Barbados, St. Kitts and Nevis and Trinidad and Tobago while the remaining set of 16 countries on their sample were classified as countries specializing in middle to low-end tourism. We have repeated the exercise by using the number of 4- and 5-star hotels in the total by doing a simple search in tourism search websites such as Orbitz and Expedia (the original source for the 2014 paper) and found that for ECCU only Anguilla is a high-end destination.

${ }^{7}$ As in Laframboise and others (2014), we use Blundell-Bond (1988) GMM estimation technique to address two important econometric problems: (i) the correlation between the explanatory variables and the unobserved country-specific effects; and (ii) the potential endogeneity of the explanatory variables.
} 
tourism is more sensitive to price changes than the rest of the Caribbean as described in Laframboise (2014), perhaps reflecting a lower relative number of high end destinations in the ECCU sample compared to the broader Caribbean sample; ${ }^{8}$ (ii) the coefficients of income and unemployment in source countries are consistently of the expected sign and significant; (iii) supply side factors such as the number of air flights are also a significant factor; and (iv) major shocks whether in the forms of natural disasters in destination countries or terror attacks in source countries can be detrimental for tourism inflows. These results are broadly in line with Laframboise and others (2014) and suggest that price is a significant factor affecting both tourism arrivals and expenditures. A one percent appreciation of the tourismweighted real effective exchange rate is associated with a 0.5 percent decrease in arrivals and a 1.2 percent decrease in tourism expenditures during 2000-2017 (Table 2). ${ }^{9}$

\section{REMOVING SUPPLY-Side CONSTRAINTS COULD BoOst COMPETITIVENESS AND THE ECCU'S MARKET SHARE}

The empirical results confirm that reducing costs and prices would be an effective strategy to bring more tourists to the ECCU. Key part of the solution would be to address the supply-side constraints and bottlenecks that limit ECCU's competitiveness on the global tourism market.

Electricity and transportation costs are high. Despite some reduction in electricity tariffs in recent years, energy costs are still very high, reflecting dependence on imported petroleum products and inefficiencies in the power sector. These inefficiencies reflect lack of economies of scale, a difficult terrain, weak institutional capacity, and deficiencies in regulatory frameworks. Consumers and producers are directly affected, with average monthly electricity bills three times as high as in the U.S. and twice the cost in most Latin American countries. The potential for increasing the use of renewable energies in the region is significant and could a have considerable impact on reducing oil dependency, tariffs, and transportation costs.

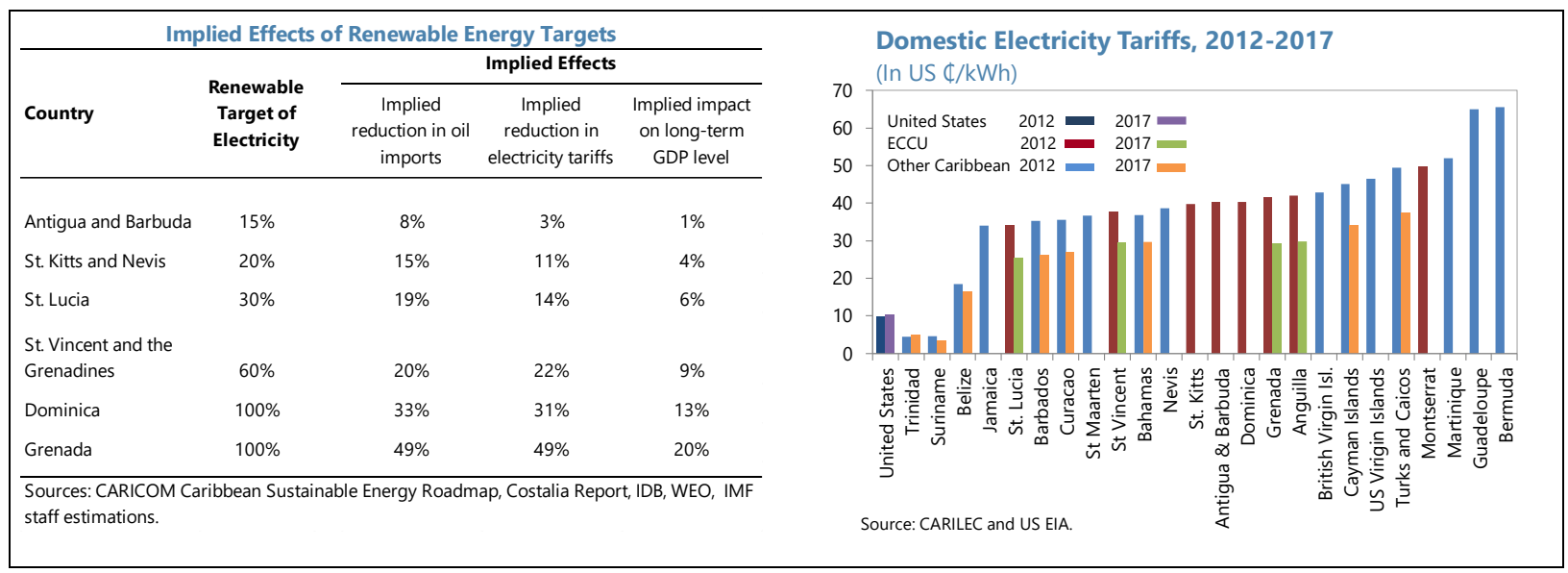

${ }^{8}$ As in Laframboise and others (2014), prices are proxied by the REER with additional robustness checks with other proxies, see Tables II.1 and II.2, pp. 21-22. The Week-at-the-Beach index is available only as of 2014.

${ }^{9}$ This price elasticity estimate is more reliable than that obtained from the gravity model owing to the broader set of variables used and the robustness to endogeneity of the estimation methodology. 
High public wages are a drag on labor markets. Evidence shows that wages in public sector and tourism lead other sectors and are only loosely linked with productivity. Public wages in the majority of ECCU members are higher than the median public wage in small states, and minimum wages in the services sector are higher than in most comparable tourist destinations globally although lower than in other Caribbean countries.

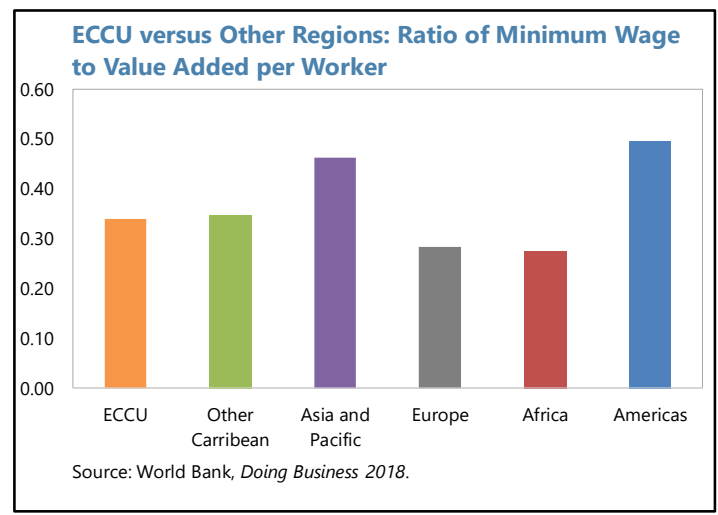

Tariffs and costs to import are high. Import costs are high compared to other countries in the world. This is especially critical as tourism, a key industry in the region, requires substantial amounts of imported intermediate goods. Elevated shipping costs and tariffs compromise the ability of businesses to operate profitably.

\section{Removal of tariffs within CARICOM and increased integration with the U.S, Canada and Latin America will benefit the ECCU.} In particular, the ECCU can implement a 0.3 percentage-point tariff cut for goods imported from other Caribbean countries and can also lower trade barriers vis-à-vis North America and Latin America. ECCU's tariffs vis a vis these countries are only lower than Caribbean 2 countries, mainly Bahamas, while in all other cases the ECCU is not competitive. Having said this, a broader consideration of the overall fiscal envelope, tax incentives and
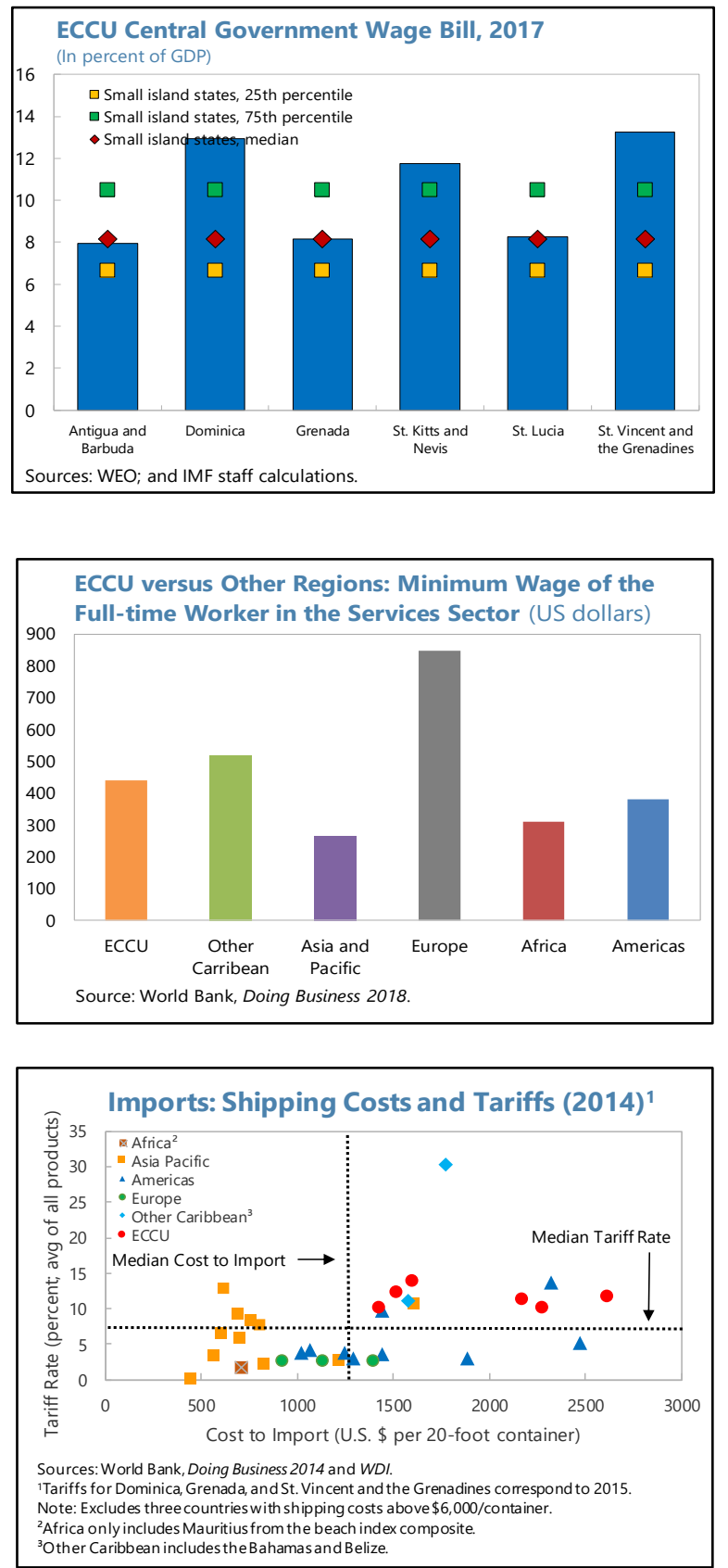

\begin{tabular}{|c|c|c|c|c|c|}
\hline \multicolumn{6}{|c|}{ Average Tariffs in Goods Trade in 2016 (percent) } \\
\hline & \multicolumn{5}{|c|}{ Partner Country Grouping } \\
\hline & ECCU & C2 & C3 & $\begin{array}{l}\text { US and } \\
\text { Canada }\end{array}$ & $\begin{array}{c}\text { Latin } \\
\text { America }\end{array}$ \\
\hline \multicolumn{6}{|l|}{ Reporting Region } \\
\hline ECCU & ... & 0.3 & 0.3 & 13.3 & 14.1 \\
\hline C2 & 6.0 & $\ldots$ & 6.7 & 18.1 & 16.4 \\
\hline o/w The Bahamas & 19.4 & $\ldots$ & 21.9 & 28.6 & 23.1 \\
\hline o/w Jamaica & 0.2 & $\ldots$ & 0.0 & 12.2 & 12.7 \\
\hline C3 & 0.0 & 0.0 & $\ldots$ & 12.3 & 13.3 \\
\hline US and Canada & 0.6 & 0.6 & 1.1 & $\ldots$ & 0.9 \\
\hline Latin America & 7.4 & 7.5 & 6.8 & 7.5 & $\ldots$ \\
\hline \multicolumn{6}{|c|}{$\begin{array}{l}\text { Source: WITS, WEO, and Fund staff estimates. } \\
\text { Note: ECCU countries are Anguilla, Antigua and Barbuda, Dominica, Grenada, Montserrat, St. } \\
\text { Kitts and Nevis, St. Lucia, and St. Vincent and the Grenadines. C2 countries are Bahamas, } \\
\text { Barbados, Belize, and Jamaica. C3 countries are Aruba, Curacao, St. Maarten, Guyana, } \\
\text { Suriname, Trinidad and Tobago. } \\
\text { Note: The values represent regional averages weighted by individual country GDPs, of simple } \\
\text { average tariffs of reporting countries imposed on partner countries. Country-level averages } \\
\text { are computed as simple averages of tariffs imposed on items with non-zero trades in the } \\
\text { reporting year. For example, the average tariffs of C1 countries on goods from the US was } 11.9 \\
\text { percent. }\end{array}$} \\
\hline
\end{tabular}


the implications from the CET (Common External Tariff) agreement with the EU may generally be given for decisions on tariffs.

Limited access to credit. Frictions affecting access to credit both for households and SMEs impede competitiveness by keeping financial sector risk sharing and diversification low and limiting capital to only large FDI related firms or hotels. Strengthening the competitiveness of the financial sector that would support the development of competitive SME market that would magnify the positive spillovers to the local markets including agri-businesses from the tourism sector becomes increasingly central as ECCU economies move towards being service oriented. Addressing financial sector competitiveness will involve improving profitability of banks financing SMEs and financial management of banks, increasing market share and optimizing the size of the sector, increasing access to credit through integrated accumulation of information and databases, such as credit bureaus among others.

Improve doing business and governance indicators is key. According to the World Bank Doing Business indicators, critical areas are access to credit and insolvency resolution. Rankings in ease of trading across borders, registering property, and paying taxes are largely in line regional peers, but well below advanced economies. Progress in any of these areas since the 2010 has been marginal. Governance indicators, such as government effectiveness, regulatory quality, and rule of law, lag peers.

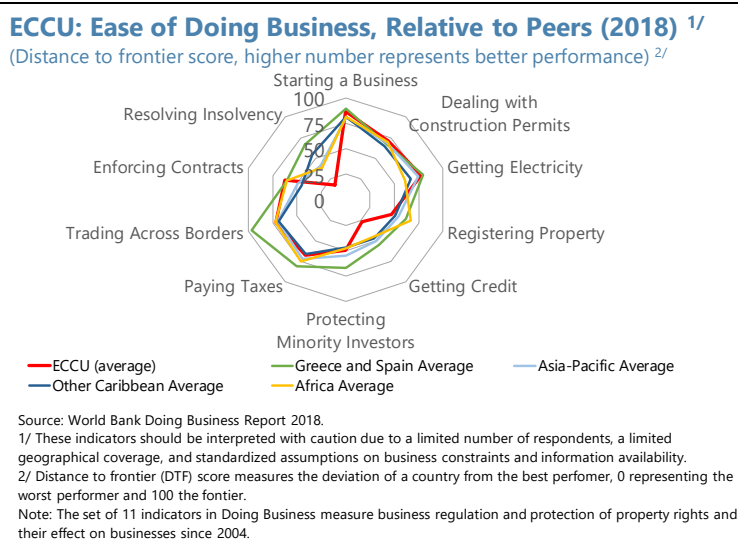

ECCU: Governance Indicators, Average Relative to Peers in tourist destinations (2016)

$(0=$ worst; 5 = best $) \quad$ Control of

Corruption1/

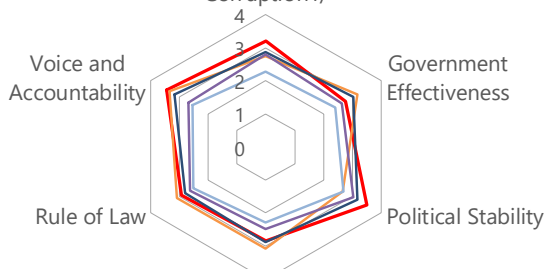

—ECCU -Europe - Asia-Pacific - Other Caribbean - Africa 1/The index captures perceptions of the extent to which public power is exercised for private gain. The rankings used are subject to uncertainty around the point estimate. Rankings reflect the relative, not the absolute performance of the country Source: Worldwide Governance Indicators (WG) is a dataset summarzing the views on the quality of governance provided by 
Simulations indicate that the impact of structural reforms on competitiveness and tourism inflows can be substantial. Using a time fixed-effects model, we estimate the impact of doing business and governance indicators and tariffs on the ECCU's global tourist market share after controlling for GDP, FDI, and the REER for the period 1995-2016 together with reproducing the actual declining share of tourist arrivals of ECCU in the week at the beach index country groups. We then re-estimate the same regression by using the averages for those indicators for the tourism destinations included in the Week-at-the-Beach index (Asia, Africa, Europe, Latin America). We rely on regression coefficients

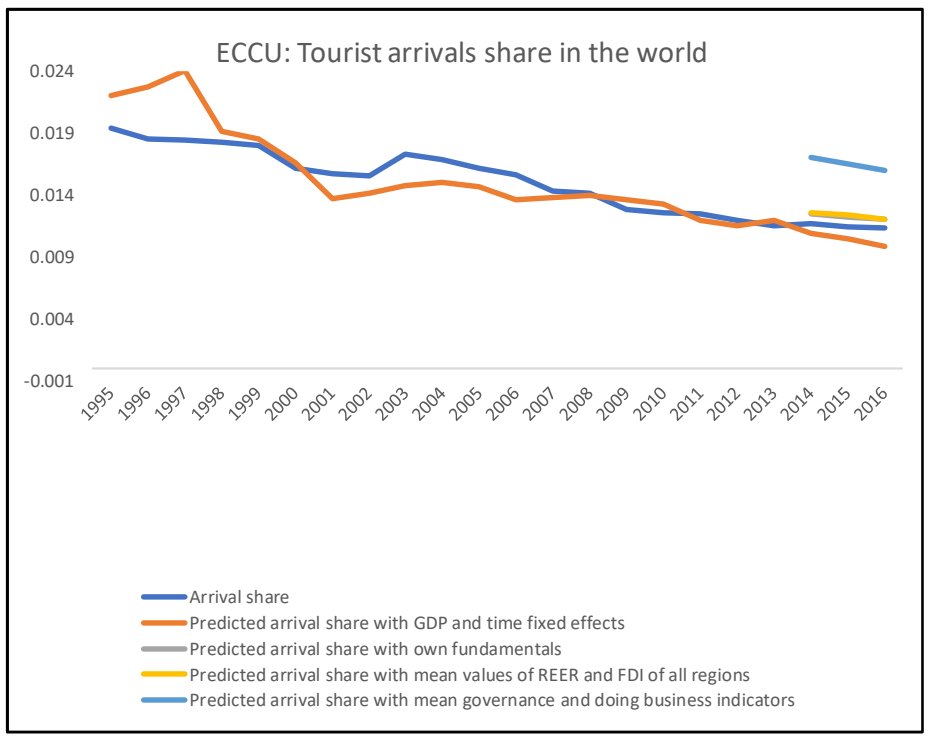
based on panel regressions for the entire sample to estimate the model, with mean values of fundamentals and the arrival shares with mean values for all regions; governance and doing business indicators are based on time and country fixed effects. Our results show that improving on doing business and governance indicators and reducing tariffs to the sample average would increase the ECCU's global market share by 40 percent. ${ }^{10}$

\section{Conclusions}

With tourism having become the main driver of economic growth and employment and the most important source of income for the ECCU, enhancing the competitiveness of the tourism product is key for these countries. Our study highlights the evidence of declining relative income, rising current account deficits, increasing external indebtedness and high structural unemployment, which altogether point to low competitiveness in the ECCU member countries. The evidence also shows that tourism arrivals to the ECCU have been declining while global demand for tourism is on the rise. To assess ECCU's competitiveness, we have applied different quantitative techniques, including a gravity model, regression analysis, and simulations to analyze the impact of structural reforms.

Proximity to the European and North American markets is a competitive advantage for ECCU in the global tourism market, which, together with the high cost structure and the relative presence of high-end destinations, can explain the high prices prevailing in the region. While source country income, airline and hotel capacities, and natural disasters are major determinants of tourism inflows to ECCU members, price is also an important factor.

\footnotetext{
${ }^{10} \mathrm{We}$ arrived at 40 percent increase in arrival share for ECCU by calculating the marginal effect of governance and business indicators over the regression estimates with mean values of the fundamentals except GDP (FDI, REER) for all tourism regions in the Week at the beach index.
} 
15

Our simulations show that improving business and governance indicators can substantially increase ECCU's global market share.

Deep structural reforms are key to increase ECCU's global market share. The evidence of a significant price elasticity underscores the necessity to lower domestic costs to capture additional source markets. This requires comprehensive structural reforms, including to reduce electricity and transportation costs, unit labor costs, as well as tariffs and cost of import. 


\section{Appendix I}

Table 1. Regression Results: Gravity Model ${ }^{1,4 /}$

Distance 2/

$-0.00068^{* * *}$

(0.00000)

Common language

$4.35278^{* * *}$

$(0.00000)$

Colonial ties

$3.50044^{* * *}$

$(0.00000)$

Weighted average of US, Canada and UK incomes per Laframboise (2014) 3/

$0.62909^{\star * *}$

$(0.00000)$

Real Effective exchange rate

$-0.16236$

$(0.18140)$

Homocide rate

0.04879

(0.71620)

Hurricanes

$-2.96071$

(0.14820)

Number of airflights

$-0.43938$

(0.06410)

Number of hotel rooms

$2.5778^{* * *}$

0.0000

Number of observations

12,931

R- squared

0.9637

Adjusted R-squared

Sources: CEPII GeoDist database; Country authorities; IMF staff estimates.

${ }^{1 /}$ The dependent variable is the log of bilateral stay-over tourist arrivals to ECCU destination i from advanced economy j (grouped as US, Canada, Europe and Other).

${ }^{2 /}$ Distance is measured in population weighted kilometers.

${ }^{3 /}$ The results replacing US income are also significant.

4/ $\mathrm{p}$ values in parenthesis. 
Table 2. Determinants of tourism arrivals and expenditure 1/

\begin{tabular}{|c|c|c|c|c|}
\hline \multirow[b]{2}{*}{ Independent variables } & \multicolumn{2}{|c|}{ Tourism arrivals } & \multicolumn{2}{|c|}{ Tourism expenditures } \\
\hline & $\begin{array}{c}\text { Caribbean sample } \\
\text { (Laframboise et al. } \\
\text { (2014)) } 2 /\end{array}$ & ECCU sample 3/ & $\begin{array}{c}\text { Caribbean sample } \\
\text { (Laframboise et al. } \\
\text { (2014)) } 2 /\end{array}$ & ECCU sample 3/ \\
\hline \multirow[t]{2}{*}{$\Delta \mathrm{Ln}$ (Tourism weighted real exchange rate ) } & $-0.158^{* * *}$ & $-.459 * *$ & $-0.105^{* * *}$ & $-1.222 * * *$ \\
\hline & $(0.00982)$ & $(0.19486)$ & $(0.0312)$ & $(0.45698)$ \\
\hline \multirow[t]{2}{*}{$\Delta \operatorname{Ln}$ (weighted average of US, Canada and UK incomes) 4/ } & $0.30 * * *$ & $.616^{* * *}$ & $0.67 * * *$ & $.681 * *$ \\
\hline & $(0.07)$ & $(0.19362)$ & $(0.14)$ & $(0.27237)$ \\
\hline \multirow[t]{2}{*}{$\Delta$ Tourism weighted unemployment rate } & $-2.081^{* * *}$ & $-2.439 * *$ & $-3.724 * * *$ & -.5094 \\
\hline & $(0.429)$ & $(1.078)$ & $(0.492)$ & $(2.102)$ \\
\hline \multirow[t]{2}{*}{$\Delta$ Hurricane $5 /$} & $-0.0138^{* *}$ & 0.0353 & $-0.0224 * *$ & 0.0185 \\
\hline & $(0.00597)$ & $(.02491)$ & $(0.00965)$ & $(.02915)$ \\
\hline \multirow[t]{2}{*}{$\Delta$ Sept.11 terrorist attacks } & $-0.0229 * * *$ & $-.0303^{* * *}$ & $-0.0286^{* *}$ & -0.01325 \\
\hline & $(0.00625)$ & $(0.00692)$ & $(0.0122)$ & $(.01266)$ \\
\hline \multirow[t]{2}{*}{$\Delta$ Homicide rate } & -0.0011 & 0.0012 & -0.00141 & -0.00088 \\
\hline & $(0.00101)$ & $(0.00072)$ & $(0.00130)$ & $(.00161)$ \\
\hline \multirow[t]{2}{*}{$\Delta \operatorname{Ln}$ (Number of airflights) } & $0.0846^{* * *}$ & $.0644^{* *}$ & $0.0928 * * *$ & 0.05652 \\
\hline & $(0.0175)$ & $(.02759)$ & $(0.0313)$ & $(0.0463)$ \\
\hline \multirow[t]{2}{*}{$\Delta \operatorname{Ln}($ Number of hotel rooms) } & -0.0104 & -.0591 & 0.0263 & 0.1053 \\
\hline & $(0.0659)$ & $(.03164)$ & $(0.0668)$ & (0.1079) \\
\hline Country fixed effects & Yes & Yes & Yes & Yes \\
\hline Observations & 141 & 72 & 139 & 72 \\
\hline Number of instruments & 133 & 70 & 131 & 70 \\
\hline
\end{tabular}

$1 /$ Robust standard errors in parenthesis.

2/ Sample 2000-2013

3/ Sample 2000-2017. To deal with the endogeneity between hotel rooms/airlines with tourism arrivals and expenditure, we use GMM Arellano-Bond regressions.

4/ Laframboise et al. (2014) use $\Delta \operatorname{Ln}$ (US household net wealth), which also significantly affects tourism arrivals and expenditures. Subsequent updates of this work use both US and

weighted average income of major tourism destinations with similar results. The authors only run panel OLS fixed effects model including these variables.

5/ Hurricanes are significant in panel OLS regressions. 


\section{References}

Acevedo, S, 2014, Debt, Growth and Natural Disasters: A Caribbean Trilogy," IMF Working Paper WP/14/125.

Acevedo, S., Han, L., Kim, M., and N. Laframboise, 2016, "Flying to Paradise: The Role of Airlift in the Caribbean Tourism Industry," IMF Working Paper WP/16/33.

Acevedo, S., Alleyne, T., and Romeu, R., 2017, "Revisiting the Potential Impact to the Rest of the Caribbean from Opening US-Cuba Tourism”, IMF Working paper WP/17/100.

Acevedo, S., and Walker, C., 2013, "The Eastern Caribbean Economic and Currency Union, Macroeconomics and Financial Systems”, edited by Schipke, A., Alinoa., and Nita.,T.

Archibald, X., LaCorbinière, J., and W. Moore, 2008, “Analysis of Tourism Competitiveness in the Caribbean: A Gravity Model Approach”, Central Bank of Barbados.

Binesware, B., 2011, "La Competitividad del Turismo en el Caribe”, Revista de la Cepal, No. 104, pp. 55-79.

Centre d'Etudes Prospectives et d'Informations Internationales (CEPII), 2015, GeoDist Database, available at: http://www.cepii.fr/CEPII/en/welcome.asp.

Di Bella, G. Mark, L., and Aurelie M., 2007, “Assessing Competitiveness and Real Exchange Rate Misalignment in Low Income Countries “, IMF Working Paper 07/201 (Washington: International Monetary Fund).

Emilio, P., Yan,S., and Cashin, P., 2010, "Assessing Exchange Rate Competitiveness in the Eastern Caribbean Currency Union", Journal of Business, Finance and Economics in Emerging Market Economies, Vol. 5, pp. 109-63.

Evridiki,T., 2008, “What Attracts Tourists to Paradise?”, IMF Working Paper 08/277.

Imam, P., 2010, “Exchange Rate Choices of Microstates,” IMF Working Paper 10/12 (Washington: International Monetary Fund).

Laframboise, N., Mwase, N., Park, J., and Y. Zhou, 2014, "Revisiting Tourism Flows to the Caribbean: What is Driving Arrivals?" IMF Working Paper WP/14/229.

Romeu, R., 2008, "Vacation Over: Implications for the Caribbean of Opening U.S.-Cuba Tourism,” IMF Working Paper WP/08/162.

Sahay R., D.O. Robinson and P. Cashin, 2006, Islands of the Caribbean: From Vulnerability to Sustained Growth, Washington: International Monetary Fund.

Tashu, M., 2013 "External competitiveness", Eastern Caribbean Economic and Currency Union, edited by Alfred, S., Aliona, C., and Tita, T., International Monetary Fund. 